\title{
VIABILITAS Lactobacillus sp F213 PADA MINUMAN RICE JUICE (Oryza sativa) SELAMA PENYIMPANAN SUHU DINGIN $\left(4^{\circ} \mathrm{C}\right)$
}

\author{
Viability of Lactobacillus sp F213 at Rice Juice (Oryza sativa) during Cold Storage $\left(4^{\circ} \mathrm{C}\right.$ ) \\ I Gusti Putu Bhuana Aristya Putra ${ }^{1}$, Agus Selamet Duniaji ${ }^{2)}$, Komang Ayu Nocianitri ${ }^{2)}$ \\ ${ }^{1)}$ Mahasiswa Program Studi Imu dan Teknologi Pangan, Fakultas Teknologi Pertanian, Unud \\ ${ }^{2}$ Dosen Program Studi Imu dan Teknologi Pangan, Fakultas Teknologi Pertanian, Unud \\ Kampus Bukit Jimbaran, Badung-Bali
}

\begin{abstract}
Lactobacillus sp F213 (LbF213) is a lactic acid bacteria isolated from a healty infant feces, which has been proven as a probiotic bacteria because it is resistant to low $\mathrm{pH}$, bile salts, digestive enzymes, able to survive and colonize the intestine, and prevent infection from E.coli pathogens. This study was conducted to know the viability of Lactobacillus sp F213 probiotic bacteria in rice juice during cold storage and its effect on the characteristics of rice juice products. This study used a descriptive method in objective tests (total lactic acid bacteria test, total glucose, $\mathrm{pH}$ and total acid) and a complete randomized design method in the subjective test (sensory test). This study used two treatments, namely rice juice with the addition of Lactobacillus sp F213 and without the addition of probiotic bacteria which are then tested every 3 days of $0,3,6,9$ and 12 in cold temperature. The test results data presented in the way form of tables and figures. The results of this study indicate that the viability of Lactobacillus sp F213 to 12 days storage at cold storage temperatures. The addition of Lactobacillus sp F213 also tends not to affect the characteristics of rice juice during storage either from the results of $\mathrm{pH}$, total acid and total glucose and from sensory characteristics such as color, aroma, taste and overall acceptance.
\end{abstract}

Keywords: probiotics, rice juice, viability, Lactobacillus sp F213

\section{PENDAHULUAN}

Makanan pada masa sekarang terutama di negara - negara maju tidak hanya mengutamakan sifat menghilangkan rasa lapar tetapi juga harus menyehatkan. Makanan sehat sangat berpengaruh bagi kesehatan fisiologis tubuh manusia. Salah satu alternatif yang dapat ditempuh untuk meningkatkan kesehatan fisiologis tubuh manusia adalah dengan mengkonsumsi bahan pangan mengandung probiotik. Probiotik adalah inggridient pangan berupa mikroba hidup yang dapat memberikan keuntungan bagi kesehatan tubuh (Salminen et al., 1998). Menurut Susanti et al.,(2007) probiotik adalah mikroorganisme hidup yang apabila diberikan dalam jumlah cukup dapat memberi efek menyehatkan bagi tubuh dengan cara memperbaiki komposisi mikrobia usus.

Lactobacillus sp F213 (LbF213) merupakan salah satu strain probiotik potensial asal Indonesia. Bakteri ini telah dipelajari secara intensif sejak tahun 2008, mulai dari skrining in vitro sampai pada uji keamanan pada manusia. LbF213 dapat beradaptasi dengan baik pada saluran pencernaan hewan dan manusia, aman pada hewan coba (Yustianan, 2009), aman pada manusia (Sujaya et al., 2016), dapat mencegah infeksi E. coli patogen (Sujaya et $a l ., 2010$ ), meningkatkan sistem imun tubuh dan menurunkan kolesterol pada hewan coba dan manusia dengan kondisi hiperkolesterolemia (Sujaya et al., 2012) dan dapat meningkatkan kenyamanan saluran cerna (Sujaya et al., 2013). Dengan potensi kesehatan yang baik tersebut, LbF213 perlu diformulasikan menjadi sebuah produk sehingga probiotik ini dapat dikonsumsi dengan mudah oleh masyarakat. Oleh karena itu pengembangan pangan fungsional mengandung probiotik LbF213 dalam bentuk produk pangan dapat mencegah penyakit metabolik dengan menjaga kesehatan dan 
keseimbangan bakteri saluran pencernaan.

Rice juice merupakan produk minuman manis hasil pemecahan pati nasi menjadi glukosa oleh ezim amylase yang dihasilkan oleh kapang Amylomyces rouxii. Amylomyces rouxii dapat menghasilkan rice juice dengan kandungan gula dan rasa yang cendrung manis. Rice juice yang mengandung glukosa menjadi substrat yang baik untuk Lactobacillus sp F213 sehingga dapat digunakan dalam pangan sebagai pembawa mikroba probiotik. Akan tetapi, gula yang tinggi juga dapat berpengaruh terhadap pertumbuhan bakteri probiotik sehingga perlu dilakukan penelitian untuk mengetahui viabilitas dari Lactobacillus sp F213 pada rice juice dengan suhu penyimpanan dingin $\left(4^{\circ} \mathrm{C}\right)$.

\section{METODE PENELITIAN}

\section{Tempat dan Waktu}

Penelitian ini dilaksanakan di UPT. Laboratorium Terpadu Biosains dan Bioteknologi Universitas Udayana Jimbaran, Jl. Raya Kampus Udayana, Bukit Jimbaran dan mulai bulan Juli-September 2018

\section{Bahan dan Alat}

Bahan yang digunakan dalam penelitian ini adalah isolat Lactobacillus sp F213 dan Amylomyces rouxii (koleksi UPT Labporatorium Terpadu dan Bioteknologi Universitas Udayana), Beras (Putri Sejati), media MRS (de man, Rogosa, Sharpe) Agar (Oxoid), MRS (de man, Rogosa, Sharpe) Broth (Oxoid), media PDA (Potato Dextrose Agar) (Merch), media BGLBB (Brilliant Green Lactose Bile Broth) (Merch), air, alkohol 96\%, akuades, $\mathrm{NaCl}$ 0,85\%, tissue, kertas saring, kristal violet, pewarna safranin, larutan lugol, aseton alkohol, Glucose Liquicolor $^{\circledR}$ (Oxidase) (Stanbio Laboratory), $\mathrm{H}_{2} \mathrm{SO}_{4}$ pekat, phenolphtalein $1 \%$.

Peralatan yang digunakan dalam penelitian ini adalah nyiru, panci, panci kukus, kain saring, baskom, kompor, cawan petri (petriq), tabung reaksi (pyrex), jarum ose, inkubator $37^{\circ} \mathrm{C}$, laminar air flow, tabung durham, spektrofotometer (genesys $10 S \mathrm{UV}$ Vis), pH-meter, buret, timbangan analitik (shimadzu Aux220), mikroskop, pipet tetes, pipet volume, labu ukur, erlenmeyer (pyrex), autoklaf, magnetik stirer, bunsen, cup plastik, sendok.

\section{Pelaksanaan Penelitian}

Pelaksanaan penelitian terdiri dari beberapa tahap yaitu:

\section{Penyegaran dan konfirmasi isolat}

Bakteri Lactobacillus sp F213 dilakukan penyegaran dengan cara diambil $100 \mu \mathrm{L}$ stok isolat yang disimpan dalam gliserol $30 \%$ pada suhu $-20^{\circ} \mathrm{C}$ dan diinokulasi pada $5 \mathrm{ml}$ media MRS Broth dan diinkubasi selama 24 jam dengan suhu $37^{\circ} \mathrm{C}$. Hasil positif ditunjukkan dengan munculnya kekeruhan pada media.

Setelah penyegaran, dilakukan konfirmasi isolat melalui uji katalase, pewarnaan gram dan uji gas. Uji katalase dilakukan dengan dibuat tetesan isolat pada gelas objek, kemudian ditetesi dengan dua tetes larutan $\mathrm{H}_{2} \mathrm{O}_{2}$, dan diamati gelembung yang timbul. Hasil positif ditunjukkan oleh timbulnya gelembung udara $\left(\mathrm{O}_{2}\right)$ yang dihasilkan dari degradasi $\mathrm{H}_{2} \mathrm{O}_{2}$ oleh enzim enzim katalase (Suryani et al., 2010)

Pewarnaan gram dilakukan dengan meneteskan isolat pada gelas objek kemudian difiksasi di atas bunsen dan diwarnai dengan kristal violet selama 1 menit, kemudian ditetesi dengan larutan lugol selama 1 menit. Selanjutnya gelas objek ditetesi aseton alkohol selama 1 menit dan terakhir diwarnai dengan pewarna safranin selama 5 detik. Sel bakteri yang telah diwarnai, dikeringkan dan diamati dibawah mikroskop (Suryani et al., 2010).

Uji gas dilakukan dengan metode hot loop, dengan cara memasukkan jarum ose panas ke dalam suspensi biakan BAL. Hasil positif ditandai oleh terbentuknya gas $\mathrm{CO}_{2}$ dan terbentuknya gelembung seperti buih dari 
hasil metabolisme glukosa (Suryani et al., 2010).

\section{Pembuatan Starter Rice juice}

Pembuatan starter rice juice (Purwandhani, et al (2008)) melalui beberapa proses yaitu:

1. Persiapan starter rice juice yaitu dari kapang Amylomyces rouxii. Kapang Amylomyces rouxii diinokulasi pada media PDA yang merupakan media selektif untuk pertumbuhan kapang dengan metode sebar dan dinkubasi selama 4 hari. Untuk uji konfirmasi dari kapang Amylomyces rouxii dilakukan dengan melihat bentuk miselia yang tumbuh dan dilihat pada mikroskop bentuk miselia dan spora.

2. Beras yang digunakan dibersihkan dan dicuci lalu rendam didalam air dengan perbandingan 1 : 1 pada suhu kamar selama 30 menit kemudian ditiriskan. Berat air yang diserap dihitung dengan menghitung pertambahan berat beras sebelum dan sesudah direndam.

3. Beras dikukus $\left( \pm 100^{\circ} \mathrm{C}\right)$ selama 30 menit dan selanjutnya diaron dengan cara menambahkan air panas dengan perbandingan beras : air yaitu $3: 2$. Proses pengaron dilakukan selama 15 menit dan dikukus kembali selama 30 menit. Berat nasi yang diperoleh ditimbang.

4. Setelah dingin, nasi diinokulasi dengan miselium kapang Amylomyces rouxii dengan cara memotong agar dengan spatula $(4 \mathrm{X} 4 \mathrm{~mm})$. Setiap 100 gr nasi dinokulasi dengan 5 buah potongan agar yang megandung miselium dan spora Amylomyces rouxii. Selanjutnya diinkubasi selama 4 hari pada suhu 32 $34^{\circ} \mathrm{C}$.

5. Nasi hasil fermentasi yaitu starter rice juice siap digunakan.

\section{Pembuatan Rice juice}

Pembuatan rice juice melalui beberapa proses yaitu:

1. Beras yang digunakan dibersihkan dan dicuci lalu rendam didalam air dengan perbandingan 1 : 1 pada suhu kamar selama 30 menit kemudian ditiriskan. Berat air yang diserap dihitung dengan menghitung pertambahan berat beras sebelum dan sesudah direndam.

2. Beras dikukus $\left( \pm 100^{\circ} \mathrm{C}\right)$ selama selama 30 menit dan selanjutnya diaron dengan cara menambahkan air panas ke dalam beras dengan perbandingan $3: 2$. Proses pengaron dilakukan selama 15 menit dan dikukus kembali selama 30 menit. Berat nasi yang diperoleh ditimbang.

3. Setelah dingin, nasi diinokulasi dengan $5 \%$ starter rice juice yang merupakan nasi fermentasi dan 5\% gula. Selanjutnya diinkubasi selama 4 hari pada suhu 32 $34^{\circ} \mathrm{C}$.

4. Nasi hasil fermentasi selanjutnya ditambahkan air dengan perbandingan 1 :

1. Kemudian diperas dengan bantuan kain saring dan didapatkan cairan rice juice. Rice juice kemudian dipasteurisasi dengan suhu $80^{\circ} \mathrm{C}$ selama 15 menit, selanjutnya dikemas kedalam botol jar steril dalam keadaan panas.

4. Inokulasi Lactobacillus sp F213 dilakukan setelah suhu rice jucie $\pm 40^{\circ} \mathrm{C}$.

\section{Inokulasi Lactobacillus sp F213 pada Rice juice}

Stok kultur Lactobacillus sp F213 diambil sebanyak $100 \mu \mathrm{l}$ dalam gliserol dan dimasukkan ke dalam $5 \mathrm{ml}$ media MRSB, lalu diinkubasi selama 24 jam pada $37^{\circ} \mathrm{C}$. Setelah inkubasi, media tersebut diamati, hasil positif ditunjukan dengan kekeruhan pada media, tabung reaksi tersebut kemudian divortex dan diambil sebanyak $1 \mathrm{ml}$, kemudian dipindahkan ke dalam tabung eppendorf untuk disentrifugasi pada kecepatan $5000 \mathrm{rpm}$ selama 10 menit. Setelah disentrifugasi, akan 
terbentuk endapan kultur mikroba pada dasar tabung eppendorf. MRSB di atas endapan kultur tersebut dibuang, sedangkan sel yang tertinggal dicuci sebanyak 3 kali. Pencucian sel dilakukan dengan cara menambahkan larutan saline ke dalam tabung eppendorf berisi endapan kultur Lactobacillus sp F213 lalu divorteks, selanjutnya eppendorf disentrifugasi pada kecepatan $5000 \mathrm{rpm}$ selama 10 menit, dan membuang supernatan yang terbentuk setelah proses sentrifugasi. Larutan saline sisa dari pencucian terakhir dibuang, kemudian diambil sebanyak $1 \mathrm{ml}$ rice juice yang sudah siap digunakan pada jar kaca $100 \mathrm{ml}$ dan dimasukkan ke dalam tabung eppendorf. Tabung eppendorf tersebut divortex dan kultur dalam eppendorf yang sudah tercampur rice juice $1 \mathrm{ml}$ dimasukkan ke dalam rice juice dalam jar kaca tadi kemudian dikocok. Rice juice tersebut kemudian disimpan pada suhu $4^{\circ} \mathrm{C}$. Diagram alir proses inokulasi bakteri probiotik Lactobacillus sp F213 dapat dilihat pada Gambar 3. Penyimpanan jus tape dilakukan selama 12 hari pada suhu $4^{\circ} \mathrm{C}$. Pada proses penyimpanan ini dilakukan pengujian setiap 3 hari mengenai karakteristik kimia dan total BAL pada hari ke-0, hari ke-3, hari ke-6, hari ke-9, hari ke-12.

\section{Rancangan Percobaan dan Analisis Data}

Penelitian ini menggunakan rancangan percobaan metode deskriptif dan rancangan acak lengkap. Metode deskriptif digunakan dalam pengujian objektif (uji total BAL, total asam, $\mathrm{pH}$ dan total glukosa) dan rancangan acak lengkap untuk pengujian subjektif (uji sensori (uji hedonik)). Penelitian ini terdiri dari dua perlakuan yaitu kontrol (tanpa penambahan LbF213) dan rice juice dengaan penambahan LbF213.

Dalam uji objektif, masing-masing perlakuan dilakukan pengulangan sebanyak 3 kali sehingga diperoleh 30 unit percobaan. Penelitian dilakukan selama 12 hari penyimpanan . Pengujian dilakukan pada hari ke-0, hari ke-3, hari ke-6, hari ke-9 dan hari ke-12 penyimpanan.

\section{Parameter yang Diamati}

Parameter yang akan diamati yaitu total BAL dengan metode sebar (Fardiaz, 1993), total asam dengan metode titrasi netralisasi (Ruck, 1963), derajat keasaman $(\mathrm{pH})$ dengan metode $\mathrm{pH}$ meter (Bouton dan Harris, 1972), total glukosa (Stanbio Laboratory) dan uji sensori (uji hedonik) (Soekarto, 1985)

\section{HASIL DAN PEMBAHASAN}

Hasil nilai rata-rata analisis total $\mathrm{BAL}$ terhadap lama penyimpanan pada rice juice yang diinokulasi Lactobacillus sp F213 dapat dilihat pada Tabel 1 dan Gambar 1.

Tabel 1. Nilai total BAL pada rice juice yang diinokulasi Lactobacillus sp F213

\begin{tabular}{ccc}
\hline \multirow{2}{*}{ Perlakuan } & \multicolumn{2}{c}{ Jumlah Total BAL } \\
& Log CFU/ml & CFU/ml \\
\hline Hari ke-0 & $6,21 \pm 0,00$ & $1,6 \times 10^{6}$ \\
Hari ke-3 & $6,89 \pm 0,09$ & $7,9 \times 10^{6}$ \\
Hari ke-6 & $6,63 \pm 0,20$ & $4,6 \times 10^{6}$ \\
Hari ke-9 & $6,61 \pm 0,37$ & $5,3 \times 10^{6}$ \\
Hari ke-12 & $6,44 \pm 0,16$ & $2,9 \times 10^{6}$ \\
\hline
\end{tabular}

Berdasarkan hasil uji total BAL, Lactobacillus sp F213 masih bisa bertahan pada produk rice juice mulai hari ke-0 hingga hari ke-12. Pertumbuhan Lactobacillus sp F213 dari penyimpanan hari ke-0 hingga hari ke-12 cendrung konstan yaitu 6,21 Log $\mathrm{CFU} / \mathrm{ml}\left(1,6 \times 10^{6} \mathrm{CFU} / \mathrm{ml}\right)$ hingga $6,44 \mathrm{Log}$ $\mathrm{CFU} / \mathrm{ml}\left(2,9 \times 10^{6} \mathrm{CFU} / \mathrm{ml}\right)$ dan tidak terjadi penurunan log pada total BAL selama 12 hari penyimpanan. Suhu penyimpanan juga mempengaruhi kemampuan bertahan hidup bakteri probiotik. Pertumbuhan konstan ini terjadi karena suhu penyimpanan dingin $\left(4^{\circ} \mathrm{C}\right)$ menyebabkan pertumbuhan Lactobacillus sp F213 melambat karena hidup dibawah suhu optimum. Suhu optimum untuk pertumbuhan probiotik antara $37-43^{\circ} \mathrm{C}$. 
Jumlah probiotik minimum yang harus sampai di sistem pencernaan / usus adalah $10^{6}$ $\mathrm{cfu} / \mathrm{g}$ atau $\mathrm{cfu} / \mathrm{mL}$ agar dapat memberikan efek kesehatan, sehingga jumlah makanan atau minuman yang mengandung probiotik yang harus dikonsumsi paling tidak berkisar $10^{7}-10^{10} \mathrm{cfu} / \mathrm{g}$ (Anurogo, 2014).

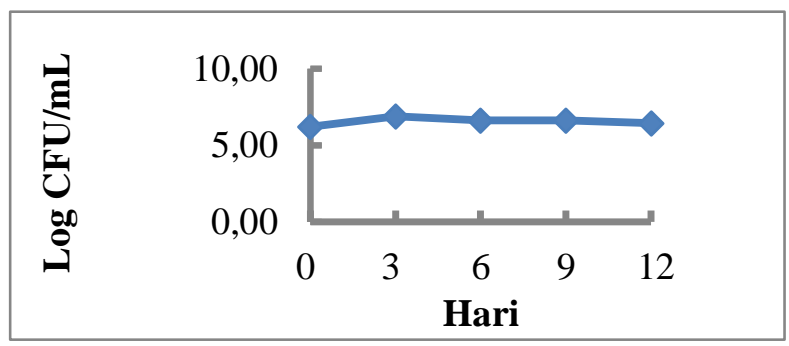

Gambar 1. Perubahan total BAL pada rice juice yang diinokulasi Lactobacillus sp F213 selama penyimpanan suhu dingin.

\section{Uji Total Glukosa}

Hasil nilai rata - rata analisis total glukosa rice juice dengan perlakuan penambahan Lactobacillus sp F213 dan kontrol (tanpa penambahan Lactobacillus sp F213) dapat dilihat pada Tabel 2 dan Gambar 2.

Tabel 2. Nilai rata - rata hasil analisis total glukosa rice juice dengan penambahan Lactobacillus sp F213 dan kontrol (tanpa penambahan Lactobacillus sp F213).

\begin{tabular}{ccc}
\hline & \multicolumn{2}{c}{ Perlakuan } \\
\cline { 2 - 3 } Penyimpanan & $\begin{array}{c}\text { Penambahan } \\
\text { Lactobacillus sp } \\
\end{array}$ & Kontrol (\%) \\
\hline Hari ke-0 & $4,20 \pm 0,14$ & $4,20 \pm 0,14$ \\
Hari ke-3 & $3,90 \pm 0,14$ & $4,16 \pm 0,15$ \\
Hari ke-6 & $3,90 \pm 0,29$ & $4,16 \pm 0,07$ \\
Hari ke-9 & $3,65 \pm 0,31$ & $3,75 \pm 0,50$ \\
Hari ke-12 & $4,07 \pm 0,04$ & $3,96 \pm 0,07$ \\
\hline
\end{tabular}

Berdasarkan hasil uji total glukosa rice juice dengan penambahan Lactobacillus sp F213 dan kontrol (tanpa penambahan Lactobacillus sp F213), nilai total glukosa sedikit menurun dan cendrung konstan dari hari ke-0 hingga hari ke-12 baik rice juice dengan penambahan LbF213 ataupun tanpa penambahan Lactobacillus sp F213. Hal ini disebabkan karena rice juice disimpan pada suhu dingin $4^{\circ} \mathrm{C}$ yang bukan pada suhu optimal bakteri probiotik tumbuh, sehingga perubahan gula yang diakibatkan oleh aktifitas LbF213 sedikit terjadi. Hal ini dapat dilihat pada Tabel 1 dan Gambar 1 dimana pertumbuhan dan Lactobacillus sp F213 cendrung konstan selama 12 hari penyimpanan. Menurut Lee dan Salminen tahun 2009 menyatakan bahwa suhu optimal untuk bakteri probiotik tumbuh yaitu antara $37-43^{\circ} \mathrm{C}$.

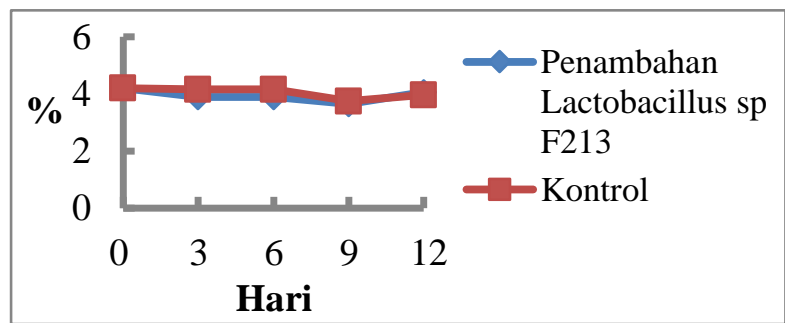

Gambar 2. Nilai rata - rata hasil analisis total glukosa rice juice dengan penambahan Lactobacillus sp F213 dan kontrol (tanpa penambahan Lactobacillus sp F213).

\section{Uji Total Asam}

Hasil nilai rata - rata analisis total asam rice juice dengan perlakuan penambahan Lactobacillus sp F213 dan kontrol (tanpa penambahan Lactobacillus sp F213) dapat dilihat pada Tabel 3 dan Gambar 3.

Berdasarkan hasil uji total asam rice juice dengan perlakuan penambahan Lactobacillus sp F213 dan kontrol (tanpa Lactobacillus sp F213), total asam mengalami sedikit peningkatan pada hari ke-0 hingga hari ke-3 tetapi cendrung konstan dari hari ke-3 hingga hari ke-12 baik dengan perlakuan penambahan Lactobacillus sp F213 dan kontrol (tanpa penambahan Lactobacillus sp F213). Peningkatan total asam terjadi karena BAL akan menghasilkan asam laktat sebagai produk utama dari fermentasi gula. Suhu penyimpanan yang lebih rendah dari suhu optimal $\left(37^{\circ} \mathrm{C}\right)$ menyebabkan Lactobacillus sp F213 berkembang lambat dan akan 
berpengaruh terhadap kemampuan menghasilkan asam dari pemecahan gula rice juice. Menurut Ayuti et.al., tahun 2016, selama proses penyimpanan suhu rendah (4$\left.10^{\circ} \mathrm{C}\right)$ pertumbuhan dan metabolisme bakteri asam laktat terjadi sangat lambat, hal ini menyebabkan sedikitnya perombakan gula menjadi asam laktat.

Tabel 3. Nilai rata-rata hasil analisis total asam rice juice dengan penambahan Lactobacillus sp F213 dan kontrol (tanpa penambahan Lactobacillus sp F213).

\begin{tabular}{ccc}
\hline & \multicolumn{2}{c}{ Perlakuan } \\
\cline { 2 - 3 } Penyimpanan & $\begin{array}{c}\text { Penambahan } \\
\text { Lactobacillus sp } \\
\text { F213 }(\%)\end{array}$ & Kontrol (\%) \\
\hline Hari ke-0 & $0,9 \pm 0,00$ & $0,96 \pm 0,10$ \\
Hari ke-3 & $1,02 \pm 0,10$ & $1,02 \pm 0,10$ \\
Hari ke-6 & $1,14 \pm 0,10$ & $1,14 \pm 0,10$ \\
Hari ke-9 & $1,02 \pm 0,10$ & $1,08 \pm 0,00$ \\
Hari ke-12 & $1,02 \pm 0,10$ & $1,14 \pm 0,10$ \\
\hline
\end{tabular}

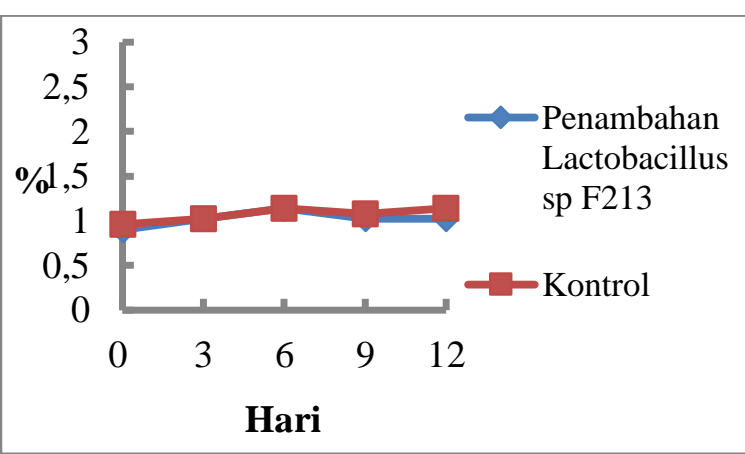

Gambar 3. Nilai rata-rata hasil analisis total asam rice juice dengan penambahan Lactobacillus sp F213 dan kontrol (tanpa penambahan Lactobacillus sp F213).

\section{Uji Derajat Keasaman (pH)}

Hasil nilai rata - rata analisis derajat keasaman $(\mathrm{pH})$ rice juice dengan perlakuan penambahan Lactobacillus sp F213 dan kontrol (tanpa penambahan Lactobacillus sp F213) dapat dilihat pada Tabel 4 dan Gambar 4.

Berdasarkan hasil uji derajat keasaman $(\mathrm{pH})$ rice juice dengan perlakuan penambahan
Lactobacillus sp F213 dan (kontrol tanpa penambahan Lactobacillus sp F213), derajat keasaman $(\mathrm{pH})$ mengalami penurunan di hari ke-3 tetapi cendrung konstan dari hari ke-3 hingga hari ke-12. Hal ini sejalan dengan nilai total asam yang mengalami peningkatan pada hari ke-3 dan cendrung konstan dari hari ke-3 hingga hari ke-12 (Tabel 3 dan Gambar 3). Tinggi rendah $\mathrm{pH}$ akan berkaitan dengan total BAL dan suhu penyimpanan. Proses fermentasi oleh BAL akan menghasilkan asam laktat sebagai produk utama dari pemecahan gula. Peningkatan total asam laktat pada produk akan menyebabkan nilai $\mathrm{pH}$ dari produk tersebut menurun. Penyimpanan pada suhu dingin juga menyebabkan terhambatnya pertumbuhan BAL sehingga kemampuan BAL untuk memecah atau mengubah gula menjadi asam berkurang.

Tabel 4. Nilai Rata-rata Hasil Analisis Derajat Keasaman $(\mathrm{pH})$ rice juice dengan perlakuan penambahan Lactobacillus sp F213 dan kontrol (tanpa penambahan Lactobacillus sp F213).

\begin{tabular}{ccc}
\hline & \multicolumn{2}{c}{ Perlakuan } \\
\cline { 2 - 3 } Penyimpanan & $\begin{array}{c}\text { Penambahan } \\
\text { Lactobacillus sp } \\
\text { F213 }\end{array}$ & Kontrol \\
\hline Hari ke-0 & $5,50 \pm 0,03$ & $5,52 \pm 0,04$ \\
Hari ke-3 & $5,33 \pm 0,02$ & $5,43 \pm 0,03$ \\
Hari ke-6 & $5,36 \pm 0,02$ & $5,42 \pm 0,02$ \\
Hari ke-9 & $5,29 \pm 0,04$ & $5,39 \pm 0,04$ \\
Hari ke-12 & $5,29 \pm 0,07$ & $5,40 \pm 0,02$ \\
\hline
\end{tabular}

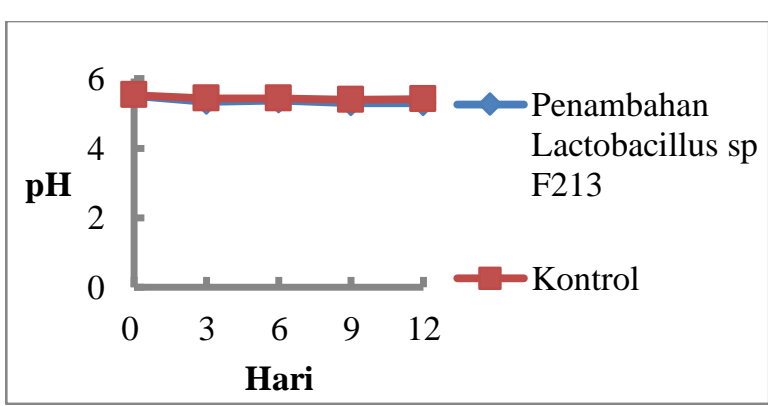

Gambar 4. Nilai Rata-rata Hasil Analisis Derajat Keasaman $(\mathrm{pH})$ rice juice dengan perlakuan penambahan Lactobacillus sp F213 dan kontrol (tanpa penambahan Lactobacillus sp F213). 


\section{Uji Sensori (Uji Hedonik)}

Uji Hedonik dilakukan terhadap aroma, warna, rasa dan penerimaan keseluruhan. Nilai rata-rata uji hedonik terhadap aroma, warna, rasa, dan penerimaan keseluruhan rice juice dengan perlakuan penambahan Lactobacillus sp F213 dan kontrol (tanpa penambahan Lactobacillus sp F213) dapat dilihat pada Tabel 5, Tabel 6, Tabel 7 dan Tabel 8

\section{Warna}

Pada Tabel 5 dapat dilihat bahwa baik dengan penambahan bakteri probiotik Lactobacillus sp F213 ataupun kontrol (tanpa penambahan Lactobacillus sp F213) berpengaruh tidak nyata $(\mathrm{P}>0,05)$ terhadap warna dari rice juice selama 12 hari penyimpanan. Kesukaan panelis terhadap warna rice juice dengan penambahan probiotik LbF213 yaitu berkisar 5,25 (agak suka) hingga 5,7 (suka). Kesukaan panelis terhadap warna rice juice kontrol yaitu berkisar 5,15 (agak suka) hingga 5,5 (suka).

Tabel 5. Nilai rata - rata Uji Hedonik Warna rice juice dengan penambahan Lactobacillus sp F213 dan kontrol (tanpa penambahan Lactobacillus sp F213).

\begin{tabular}{|c|c|c|}
\hline \multirow[b]{2}{*}{ Penyimpanan } & \multicolumn{2}{|c|}{ Warna } \\
\hline & $\begin{array}{l}\text { Penambahan } \\
\text { LbF213 }\end{array}$ & Kontrol \\
\hline Hari ke-0 & $5,25 \pm 1,21 a$ & $5,15 \pm 1,14 \mathrm{a}$ \\
\hline Hari ke-3 & $5,40 \pm 1,14 \mathrm{a}$ & $5,50 \pm 1,19 \mathrm{a}$ \\
\hline Hari ke-6 & $5,70 \pm 1,03 \mathrm{a}$ & $5,15 \pm 1,23 \mathrm{a}$ \\
\hline Hari ke-9 & $5,35 \pm 1,18 \mathrm{a}$ & $5,20 \pm 1,61 \mathrm{a}$ \\
\hline Hari ke-12 & $5,30 \pm 1,22 \mathrm{a}$ & $5,50 \pm 1,15 \mathrm{a}$ \\
\hline \multicolumn{3}{|c|}{$\begin{array}{l}\text { Kriteria: Nilai rata - rata yang diikuti oleh huruf yang } \\
\text { berbeda pada kolom yang sama menunjukkan } \\
\text { berbeda nyata }(\alpha=0,05) .\end{array}$} \\
\hline \multicolumn{3}{|c|}{ 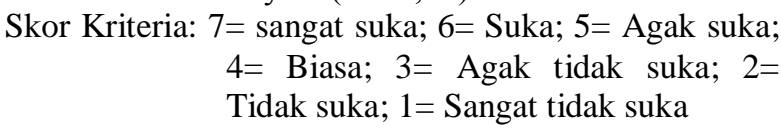 } \\
\hline
\end{tabular}

Menurut Winarno (2004) warna merupakan komponen yang sangat penting untuk menentukan kualitas atau derajat penerimaan suatu bahan pangan. Warna merupakan kesan pertama yang terlihat sebelum seseorang mengkonsumsi suatu pangan. Suatu bahan pangan meskipun dinilai enak dari segi rasa, aroma dan sebagainya, tetapi memiliki warna yang tidak menarik atau memberi kesan telah menyimpang dari warna yang seharusnya maka bahan tersebut tidak akan dikonsumsi. Penentuan mutu suatu bahan pangan pada umumnya tergantung pada warna karena warna tampil terlebih dahulu.

\section{Aroma}

Pada Tabel 6 dapat dilihat bahwa baik dengan penambahan bakteri probiotik Lactobacillus sp F213 ataupun kontrol (tanpa penambahan Lactobacillus sp F213) berpengaruh tidak nyata $(\mathrm{P}>0,05)$ terhadap aroma dari rice juice. Kesukaan panelis terhadap aroma rice juice dengan penambahan LbF213 berkisar 4,55 (agak suka) hingga 5,25 (agak suka). Kesukaan panelis terhadap aroma rice juice kontrol berkisar 4,80(agak suka) hingga 5 (agak suka).

Tabel 6. Nilai rata - rata Uji Hedonik Aroma rice juice dengan penambahan Lactobacillus sp F213 dan kontrol (tanpa penambahan Lactobacillus $\mathrm{sp}$ F213).

\begin{tabular}{lrc}
\hline \multirow{2}{*}{ Penyimpanan } & \multicolumn{2}{c}{ Aroma } \\
\cline { 2 - 3 } & Penambahan LbF213 & Kontrol \\
\hline Hari ke-0 & $4,65 \pm 1,63 \mathrm{a}$ & $5,00 \pm 1,26 \mathrm{a}$ \\
Hari ke-3 & $5,25 \pm 1,33 \mathrm{a}$ & $4,80 \pm 1,47 \mathrm{a}$ \\
Hari ke-6 & $5,05 \pm 1,28 \mathrm{a}$ & $4,85 \pm 1,50 \mathrm{a}$ \\
Hari ke-9 & $4,55 \pm 1,50 \mathrm{a}$ & $4,85 \pm 1,53 \mathrm{a}$ \\
Hari ke-12 & $5,00 \pm 1,59 \mathrm{a}$ & $4,80 \pm 1,32 \mathrm{a}$ \\
\hline
\end{tabular}

Kriteria: Nilai rata - rata yang diikuti oleh huruf yang berbeda pada kolom yang sama menunjukkan berbeda nyata $(\alpha=0,05)$.

Skor Kriteria: $7=$ sangat suka; $6=$ Suka; $5=$ Agak suka; 4= Biasa; 3= Agak tidak suka; $2=$ Tidak suka; $1=$ Sangat tidak suka

Menurut Meilgaard, et al. (2000) menyatakan bahwa aroma makanan timbul disebabkan oleh terbentuknya senyawa volatil yang mudah menguap, selain itu proses 
pemasakan yang berbeda akan menimbulkan aroma yang berbeda. Lama penyimpanan tidak berpengaruh nyata terhadap aroma rice juice karena melalui proses penyimpanan dingin baik BAL ataupun mikroba lainnya yang tumbuh didalam rice juice berkembang lambat dan cendrung konstan (dapat dilihat pada uji total BAL). Hal ini menyebabkan pemecahan zat - zat yang kemungkinan menyebabkan aroma volatile pada rice juice terhambat dengan perlakuan penyimpanan suhu dinging dari hari ke-0 hingga hari ke-12.

\section{Rasa}

Pada Tabel 7 dapat dilihat bahwa baik dengan penambahan bakteri probiotik Lactobacillus sp F213 ataupun kontrol (tanpa penambahan Lactobacillus sp F213) berpengaruh tidak nyata $(\mathrm{P}>0,05)$ terhadap rasa dari rice juice selama 12 hari penyimpanan. Kesukaan panelis terhadap rasa rice juice dengan penambahan $\mathrm{LbF} 213$ yaitu berkisar 5,15 (agak suka) hingga 5,55 (suka). Kesukaan panelis terhadap rasa rice juice kontrol yaitu berkisar 5,25 (agak suka) hingga 5,65 (suka).

Tabel 7. Nilai rata - rata Uji Hedonik Rasa rice juice dengan penambahan Lactobacillus sp F213 dan kontrol (tanpa penambahan Lactobacillus sp F213).

\begin{tabular}{lcc}
\hline \multirow{2}{*}{ Penyimpanan } & \multicolumn{2}{c}{ Rasa } \\
\cline { 2 - 3 } & $\begin{array}{c}\text { Penambahan } \\
\text { LbF213 }\end{array}$ & Kontrol \\
\hline Hari ke-0 & $5,20 \pm 1,24 \mathrm{a}$ & $5,25 \pm 1,29 \mathrm{a}$ \\
Hari ke-3 & $5,50 \pm 1,40 \mathrm{a}$ & $5,65 \pm 0,93 \mathrm{a}$ \\
Hari ke-6 & $5,55 \pm 1,15 \mathrm{a}$ & $5,40 \pm 1,05 \mathrm{a}$ \\
Hari ke-9 & $5,35 \pm 1,27 \mathrm{a}$ & $5,30 \pm 1,03 \mathrm{a}$ \\
Hari ke-12 & $5,15 \pm 1,27 \mathrm{a}$ & $5,25 \pm 1,29 \mathrm{a}$ \\
\hline
\end{tabular}

Kriteria: Nilai rata - rata yang diikuti oleh huruf yang berbeda pada kolom yang sama menunjukkan berbeda nyata $(\alpha=0,05)$.

Skor Kriteria: $7=$ sangat suka; $6=$ Suka; $5=$ Agak suka; 4= Biasa; 3= Agak tidak suka; 2= Tidak suka; $1=$ Sangat tidak suka

Menurut Khasanah (2003), rasa adalah faktor yang dinilai panelis setelah tekstur, warna dan aroma yang dapat yang mempengaruhi penerimaan produk pangan. Rasa timbul akibat adanya rangsangan kimiawi yang dapat diterima oleh indera pencicip atau lidah. Rasa yang enak dapat menarik perhatian sehingga konsumen lebih cenderung menyukai makanan dari rasanya. Jika komponen aroma, warna dan tekstur baik tetapi konsumen tidak menyukai rasanya maka konsumen tidak akan menerima produk pangan tersebut. Lama penyimpanan tidak berpengaruh nyata terhadap rasa rice juice karena melalui proses penyimpanan dingin baik BAL ataupun mikroba lainnya yang tumbuh didalam rice juice berkembang lambat dan cendrung konstan (dapat dilihat pada uji total BAL). Hal ini menyebabkan pemecahan zat - zat seperti gula dan asam asam yang menimbulkan rasa manis keasaman pada rice juice terhambat dengan perlakuan penyimpanan suhu dinging dari hari ke-0 hingga hari ke-12.

\section{Penerimaan Keseluruhan}

Pada Tabel 8 dapat dilihat bahwa baik dengan penambahan bakteri probiotik Lactobacillus sp F213 ataupun kontrol (tanpa penambahan Lactobacillus sp F213) berpengaruh tidak nyata $(\mathrm{P}>0,05)$ terhadap rasa dari rice juice. Kesukaan panelis terhadap rasa rice juice dengan penambahan Lactobacillus sp F213 yaitu berkisar 5,05 (agak suka) hingga 5,55 (suka). Kesukaan panelis terhadap rasa rice juice kontrol yaitu berkisar 5,05 (agak suka) hingga 5,50 (suka). Nilai rata - rata kesukaan keseluruhan tersebut menunjukkan bahwa rice juice dengan penambahan bakteri probiotik Lactobacillus sp F213 ataupun tanpa penambahan Lactobacillus sp F213dapat diterima dengan cukup baik oleh panelis. 
Tabel 8. Nilai rata - rata Uji Hedonik Penerimaan Keseluruhan rice juice dengan penambahan Lactobacillus sp F213 dan kontrol (tanpa penambahan Lactobacillus sp F213).

\begin{tabular}{lcc}
\hline \multirow{2}{*}{ Penyimpanan } & \multicolumn{2}{c}{ Penerimaan Keseluruhan } \\
\cline { 2 - 3 } & $\begin{array}{c}\text { Penambahan } \\
\text { LbF213 }\end{array}$ & Kontrol \\
\hline Hari ke-0 & $5,15 \pm 0,99$ a & $5,05 \pm 1,15 \mathrm{a}$ \\
Hari ke-3 & $5,40 \pm 1,05 \mathrm{a}$ & $5,50 \pm 1,19 \mathrm{a}$ \\
Hari ke-6 & $5,55 \pm 1,00 \mathrm{a}$ & $5,20 \pm 1,11 \mathrm{a}$ \\
Hari ke-9 & $5,35 \pm 1,27 \mathrm{a}$ & $5,20 \pm 1,06 \mathrm{a}$ \\
Hari ke-12 & $5,05 \pm 1,15 \mathrm{a}$ & $5,10 \pm 1,37 \mathrm{a}$ \\
\hline
\end{tabular}

Kriteria: Nilai rata - rata yang diikuti oleh huruf yang berbeda pada kolom yang sama menunjukkan berbeda nyata $(\alpha=0,05)$.

Skor Kriteria: $7=$ sangat suka; $6=$ Suka; $5=$ Agak suka; 4= Biasa; 3= Agak tidak suka; $2=$ Tidak suka; $1=$ Sangat tidak suka

\section{KESIMPULAN DAN SARAN}

\section{Kesimpulan}

Berdasarkan hasil penelitian yang telah dilakukan, maka dapat disimpulkan beberapa hal sebagai berikut :

1. Bakteri Lactobacillus sp F213 mampu bertahan pada rice juice hingga hari ke12 pada penyimpanan suhu dingin $\left(4^{\circ} \mathrm{C}\right)$.

2. Bakteri Lactobacillus sp F213 tidak mempengaruhi karakteristik rice juice selama penyimpanan 12 hari pada suhu dingin terhadap nilai total $\mathrm{BAL}, \mathrm{pH}$, total asam dan total glukosa serta karakteristik sensori rice juice seperti warna, aroma, rasa dan penerimaan keseluruhan yang agak disukai oleh panelis.

\section{Saran}

Dalam usaha untuk mencapai standar konsumsi probiotik yaitu sebesar $10^{7} \mathrm{CFU} / \mathrm{ml}$, perlu dilakukan peningkatan jumlah koloni yang diinokulasi ke produk rice juice.

\section{DAFTAR PUSTAKA}

Anurogo, D. 2014. Probiotik: problematika dan progresivitasnya. Medical Review. 27(3): 46-57.

Ayuti, S. R., Nurliana, Yurliasni, Sugito dan Darmawati. 2016. Dinamika Pertumbuhan Lactobacillus casei dan Karakteristik Susu Fermentasi Berdasarkan Suhu dan Lama Penyimpanan. Agripet. Vol 16. No 1.

Bouton, P. E. dan P.V. Harris. 1972. All About Yoghurt. Prentice Hall, Inc., Englewood Cliffs, New Jersey.

Ding, W. K. dan N. P. Shah. 2008. Survival of Free and Microencapsulated Probiotic Bacteria in Orange and Apple Juices. International Food Journal 15 (2): 219-232

Fardiaz, S. 1993. Perhitungan Total Populasi BAL pada Yoghurt. Diakses melalui $e$ journal 7-8 pada 20 Mei 2018.

Khasanah, U. 2003. Karakteristik FisikoKimia dan Organoleptik Produk Makanan sarapan Ubi Jalar (Sweet Potato Flakes). IPB. Bogor.

Meilgaard, M., G.V.Civille, B.T. Carr. 2000. Sensory Evaluation Techniques. CRC Press. Boca Raton, Florida

Purwardhani, S.N., Rahayu, E.S., dan Suladra. M. 2008. Efektivitas Suplementasi Agensia Probiotik Lactobacillus acidophilus Snp-2 Pada Pembuatan Tape Ketan dan Brem. Jurnal Agritech Vol. 8

Ruck. 1963. Hot-Loop Test for the Determination of Carbon Dioxide Production from Glucose by lactid Acid Bakteria. Appl. Environ Microbial 6(36): 990-991. 
Salminen S, C Bouley, MC Boutron-Ruault, Cumings JH, Franck A, Gibson GR, Isolauri E, Moreau MC, Roberfroid M, and Rowland I. 1998. Functional food science and gastrointestinal physiology and function. Br J Nutr, 80 (suppl) : S147-71.

Sujaya, I N. 2010. Development of Probiotic for Diarrheagenic Pathogens. International Symposium on Bioscinece and Biotechnology, Udayana University, 1417 Sept. 2010

Sujaya, I.N, I.D.M Sukrama, Y. Ramona, K.A Nocianitri, T Sone, K Asano. 2012. Resistantce of Lactobacillus sp. F213 in human gastrointestinal tract as reveal by Polymerase Chain Reaction-Denaturing Gradient Gel Electrophoresis of fecal microbiome. (Laporan penelitian kerja sama luar negeri, Universitas Udayana).

Sujaya, I.N, I.D.M Sukrama, Y. Ramona, K.A Nocianitri, T Sone, K Asano. 2013. Resistantce of Lactobacillus sp. F213 in human gastrointestinal tract as reveal by Polymerase Chain Reaction-Denaturing Gradient Gel Electrophoresis of fecal microbiome. (Laporan penelitian kerja sama luar negeri, Universitas Udayana).

Sujaya, I N., K.A. Nocianitri, Y. Ramona, I.D.M. Sukrama, M.A.Wirawan, N.N.D. Fatmawati. 2016. Lama kolonisasi Lactobacillus sp F213 pada saluran pencernaan dalam upaya pengembangan probiotik untuk menurunkan kolesterol. Penelitian Strategis Nasional, (Laporan).

Suryani, Y., A. B. Oktavia dan S. Umniyati. 2010. Isolasi dan Karakterisasi Bakteri Asam Laktat dari Limbah Kotoran Ayam sebagai Agensi Probiotik dan Enzim Kolesterol Reduktase. Biologi dan Pengembangan Profesi Pendidik Biologi. Biota. 12 (3): 177-185.
Susanti, I., Pramudiyanto, K., dan Munandar. J. 2007. Kajian Penambahan Stabilizer terhadap Kualitas Yoghurt Probiotik Dalam Seminar Nasional PATPI 2007. Bandung

Soekarto, S. T. 1985. Penilaian Organoleptik. Bharata Karya Aksara : Jakarta

Winarno, F.G., 2004. Kimia Pangan dan Gizi. Gramedia Pustaka Utama. Jakarta.

Yustianan, P.S. 2009. Aspek keamanan dari Lactobacillus sp F213 dalam pengembangannya sebagai probiotik endogen Indonesia. Skripsi PS Farmasi, FMIPA Unud. 